\title{
DELINEATION OF GROUNDWATER POTENTIAL ZONE IN THE INDO-GANGETIC PLAIN THROUGH GIS ANALYSIS
}

\section{Dinesh Pathak}

Journal of Institute of Science and Technology

Volume 22, Issue 1, July 2017

ISSN: 2469-9062 (print), 2467-9240 (e)

\section{Editors:}

Prof. Dr. Kumar Sapkota

Prof. Dr. Armila Rajbhandari

Assoc. Prof. Dr. Gopi Chandra Kaphle

JIST, 22 (1): 104-109 (2017)

Published by:

Institute of Science and Technology

Tribhuvan University

Kirtipur, Kathmandu, Nepal 


\title{
DELINEATION OF GROUNDWATER POTENTIAL ZONE IN THE INDO-GANGETIC PLAIN THROUGH GIS ANALYSIS
}

\author{
Dinesh Pathak \\ Central Department of Geology, Geodisaster Research Center, Tribhuvan University, Kirtipur, Nepal \\ Corresponding E-mail: dpathaktu@gmail.com
}

\begin{abstract}
Water availability for domestic and irrigation purpose is the lifeline of the society and plays a dominant factor in the agriculture development of the country. Though Nepal is rich in water resources, nation-wide surface water irrigation network is yet to be established to meet the year round irrigation. The readily available shallow groundwater is considered as vital in meeting the domestic and irrigation water need. The shallow groundwater irrigation in the country has been emphasized and this system is contributing in the irrigation facility at present. Understanding the potential of shallow groundwater would support to further develop the shallow irrigation cluster wells in the Indo-Gangetic Plain. A systematic and comprehensive tube well database in GIS platform serves better for the groundwater potential delineation purpose. Thicknesses of aquifer material, well yield, hydraulic conductivity, water table are some of the decisive parameters for delineating the groundwater potential areas. However, all parameters are not always available. In such situation, the analysis can be performed with the thickness of aquifer material and yield of the well that are widely available in the reports of concerned organizations. Present study shows the GIS based analysis of aquifer parameters in one of the Terai districts of Nepal to delineate the shallow groundwater potential zones. The method adopted in the present study can be applied in other parts of the country, which would better serve for effective development planning and providing irrigation service to the farmers.
\end{abstract}

Keywords: Indo-Gangetic plain, Aquifer parameter, Groundwater potential, GIS analysis, Groundwater irrigation.

\section{INTRODUCTION}

Out of the total 147, 18, 100 ha area of Nepal, only $26,41,100$ ha is suitable for the agriculture. The total irrigable land is reported to be only $67 \%(17,66,000 \mathrm{ha})$ of the total cultivated land (26, 41, 000 ha). The steep mountainous terrain has greatly reduced the possibility of surface and groundwater irrigation. Because of the limited agricultural land and increasing population, the Government of Nepal has emphasized on the irrigation infrastructure to increase the agriculture production. Under the Agricultural Perspective Plan (APP) and Community Ground Water Irrigation Project (CGISP) large number of shallow tube well (STW) and deep tube well (DTW) have been installed to irrigate a vast agricultural land through the groundwater. The identification of groundwater potential zone is necessary to further develop irrigation cluster wells for the exploitation of groundwater resources. In addition, it is equally important to manage the sustainable utilization of the resource.

Geographic information system is widely used in identification of the groundwater potential zone and recharge areas (Ali et al., 2015; Naveenkumar et al., 2015; Suganthi et al., 2013; Magesh et al., 2011; Srinivasa \& Jugran, 2003). It is realized that delineation of groundwater potential zones by using GIS is convenient and time saving as large number of data can be handled in the GIS. This paper is intended to present a method to delineate shallow groundwater potential in the Terai plain using GIS application with an example of Rupandehi district, west Nepal. Thus produced map will be useful for an effective development planning and providing service to the farmers of the district.

\section{THE STUDY AREA}

The Rupandehi district lie in the Lumbini Zone of western developmental region and occupies an area of $1304 \mathrm{~km}^{2}$ consisting of 72 village development 
committees and two municipalities (Figure 1). The district is occupied both by the mountainous regions (Churia Hills) in the northern part and the plain areas (Terai Plain) in the southern part. Eastwest Highway is traversing through the northern part of the Terai Plain.

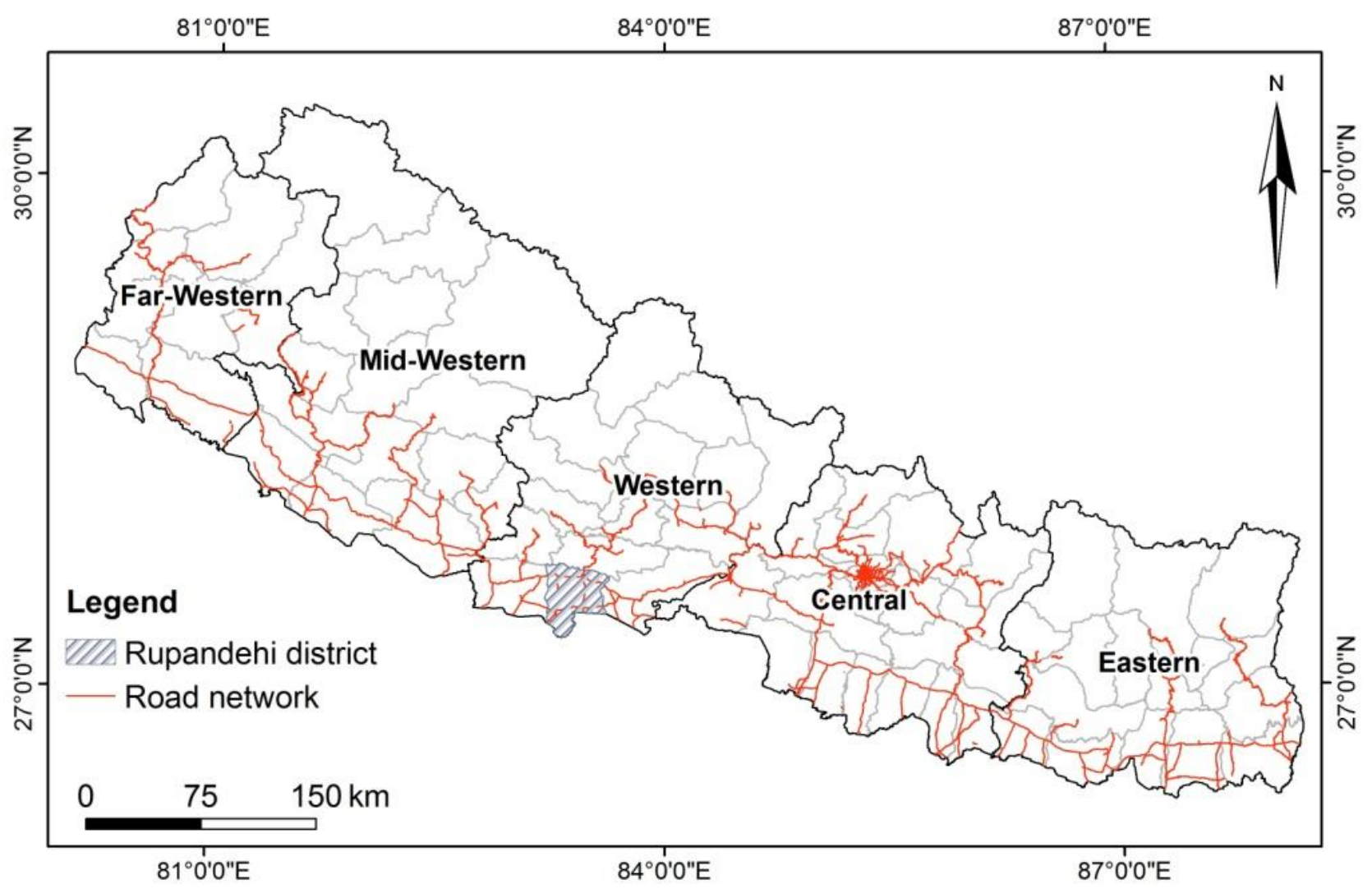

Fig. 1. Location map of Rupandehi district.

The north-south flowing Tinau River is the main river in the district. Besides, the Bhaluhi/Danda River in the east and Danav River in the west are other rivers traversing the district (Figure 2). The southern part of the district is the plain areas with vast agriculture land with patches of forest where the groundwater irrigation project has been implemented. The northernmost part of the area is dominantly occupied by the forest. The forest covered area lying in the north and western part of the study area is the potential area of recharge for the entire southern part of the district. In addition, direct recharge takes place from the areas in the south where coarser materials are distributed (Rao \& Pathak, 1996).

There are both the unconfined and confined aquifers. The confined aquifers occur at different depth resulting in multi-aquifer systems. Shallow tube well and deep tube wells are tapping these aquifers and the discharge of the wells depends upon the aquifer characteristics.

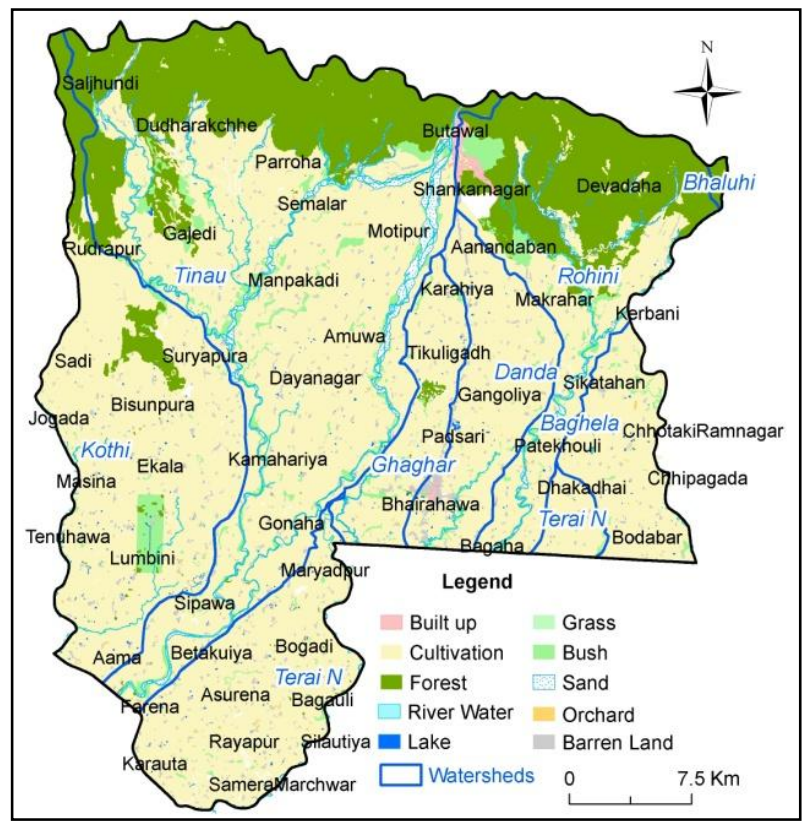

Fig. 2. Land use map of Rupandehi district. 
The Rupandehi district is geologically represented by Churia region (Siwalik), Bhabar zone and Terai Plain from north to south (Figure 3). The plain area occupies the Bhabhar zone and Terai Plain. A number of streams originating in the Churia Range in the north deposits coarser materials (boulder, cobble, pebble, sand) as fan deposits along the foothills forming the Bhabar zone and the grain size of the deposits becomes finer southwards (Terai Plain).

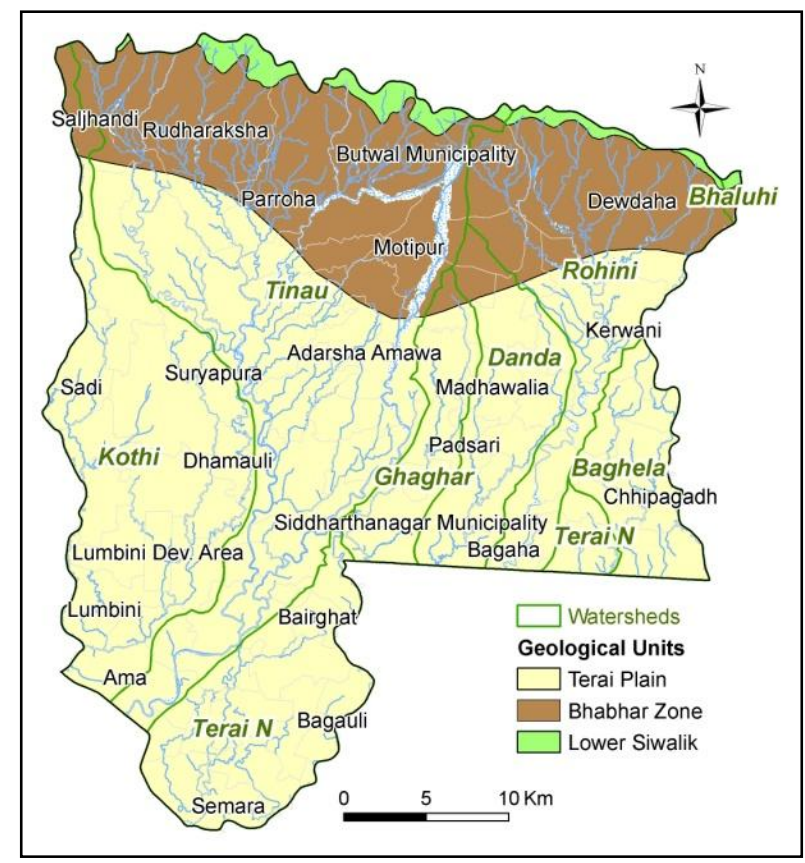

Fig. 3. Geological map of Rupandehi district.

The Bhabhar zone with poorly sorted sediments and very high permeability is considered as the major recharge zone for the aquifer lying in the further southwards. The area of Bhabhar zone is estimated to more than $100 \mathrm{~km}^{2}$ in Rupandehi district (Tillson, 1985). The Terai Plain deposits lie southward of the Bhabar zone and consist of relatively finer sediments (gravel, sand, silt and clay). Because of their fluviatile origin and with shifting nature of stream channels, these deposits are cross-bedded, eroded, reworked and redeposited. The southern part of the Bhabar zone can be demarcated through the presence of spring line mainly on the river originating from the Siwalik Hills. It is because of the difference in elevation and grain size between the Bhabar and Terai sediments.

\section{MATERIALS AND METHODS}

In order to prepare the groundwater potential map of the district, primary and secondary data were collected. The available literature, reports, data and maps were collected. The information on hard copy maps was converted into digital data through digitization. GPS survey was carried out to acquire the well coordinate (when required). A GIS database has been prepared with the well location and aquifer characteristics for respective shallow tube wells. Total of 322 well data forms the GIS database, which includes USAID (United States Agency for International Development), UNDP (United Nations Development Program), APP (Agricultural Perspective Plan), BLGWP (Bhairahawa-Lumbini Groundwater Project) and JRC (Japan Red Cross) drilled wells (Tibbitts et al., 1973; Upreti, 1989; GDC, 1994a \& 1994b; BLGWP, 1998a \& 1998b).

The shallow aquifer lying within the depth of $25 \mathrm{~m}$ from the top has been considered for the preparation of shallow groundwater potential map. The thematic layers like percentage of aquifer materials, yield, water level (m bgl) were interpolated to raster and grid data was formed. Thus formed grid map was classified as per the classification criteria mentioned in Table 1.

Table 1. Class interval of parameter values for shallow aquifer $(<25 \mathrm{~m} \mathrm{bgl})$.

\begin{tabular}{|l|l|l|l|}
\hline S. N. & Category & Aquifer material \% & Yield (lps) \\
\hline 1 & Very low & $<15$ & $<10$ \\
\hline 2 & Low & $15-30$ & $10-15$ \\
\hline 3 & Moderate & $30-45$ & $15-20$ \\
\hline 4 & High & $45-60$ & $20-25$ \\
\hline 5 & Very high & $>60$ & $>25$ \\
\hline
\end{tabular}


The parameter maps were then combined to get the shallow groundwater potential map in the study area. The thematic maps were rasterized and then spatial analysis was carried out to combine the output maps. The resulting map was further reclassified into different shallow aquifer potential zones.

\section{RESULTS AND DISCUSSION Water table}

The water table map of Rupandehi district for the shallow aquifer shows that the Butwal Municipality area is having deepest water table ( $>14 \mathrm{~m} \mathrm{bgl})$ and hence the shallow wells are not feasible in this area. This zone lies in the Bhabhar zone which is obviously having deeper water table. The area lying between Pharsatikar in the north and confluence of Tinau River and Danav River in the south has flowing zone, which are mostly the deep wells.

\section{Aquifer potential}

More than 200 shallow wells with the record of lithological logs in the district have been used to assess the various aquifer layers within the depth of $25 \mathrm{~m}$ in the study area. It is observed that there is the presence of coarse aquifer materials in the central north of the district lying south of the eastwest highway, while the area around the Kothi River in the southwest is characterized by the high clay to fine sand aquifer materials. This fact is indicating the deposition of coarser materials by the Tinau River in the northern part. This can be evidenced from the distribution of higher percentages of aquifer material in the shallow aquifer in this zone (Figure 4).

Besides, around the villages Belahiya, Gobrauli and Madhubani lying north to south in the western part of the district, the shallow aquifer has higher percentages $(>40 \%)$ of aquifer materials.

\section{Yield potential}

In the Rupandehi district, there are 46 wells with yield values measured through pumping test. The high well yield lies in the northern part (Jogikuti and Driver Tole villages) of the Rupandehi district, around the Tinau River and there is the zone of moderate yield along the Danav River in the west of the district (Figure 5). Likewise, the lowest yield values $(<10 \mathrm{lps})$ lies around the Dayanagar VDC in the central western part of the district. The moderate yield $(15-20 \mathrm{lps})$ zone is extended from Kerwani VDC in the east to Tikuligadh VDC in the centre and Suryapura VDC in the west.

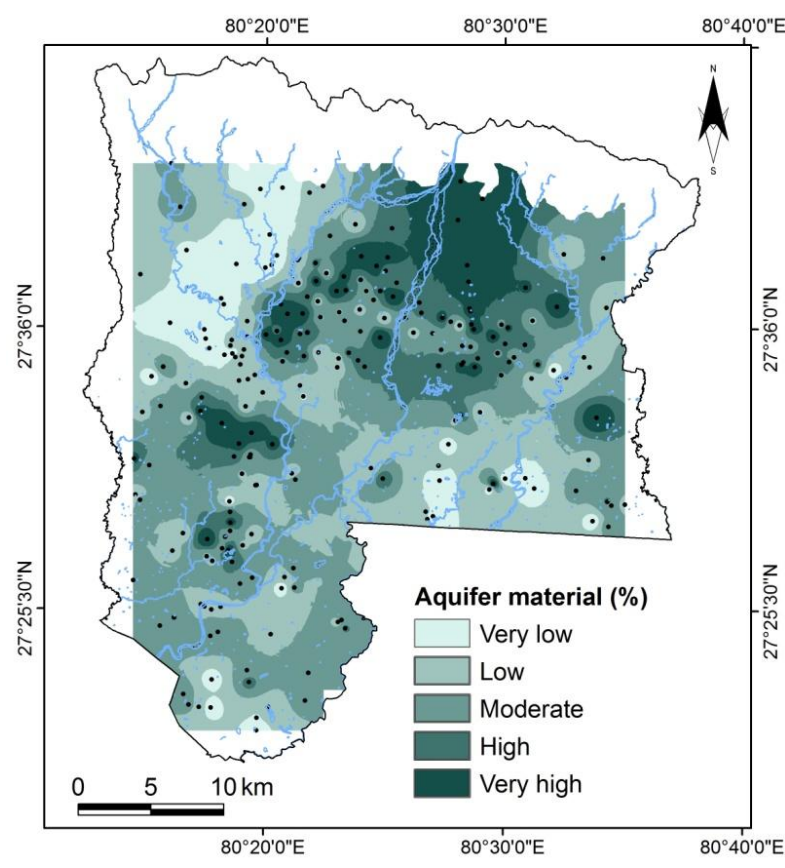

Fig. 4. Percentage of aquifer material within $25 \mathrm{~m}$ depth (the black dot represents the locations of wells used in the analysis).

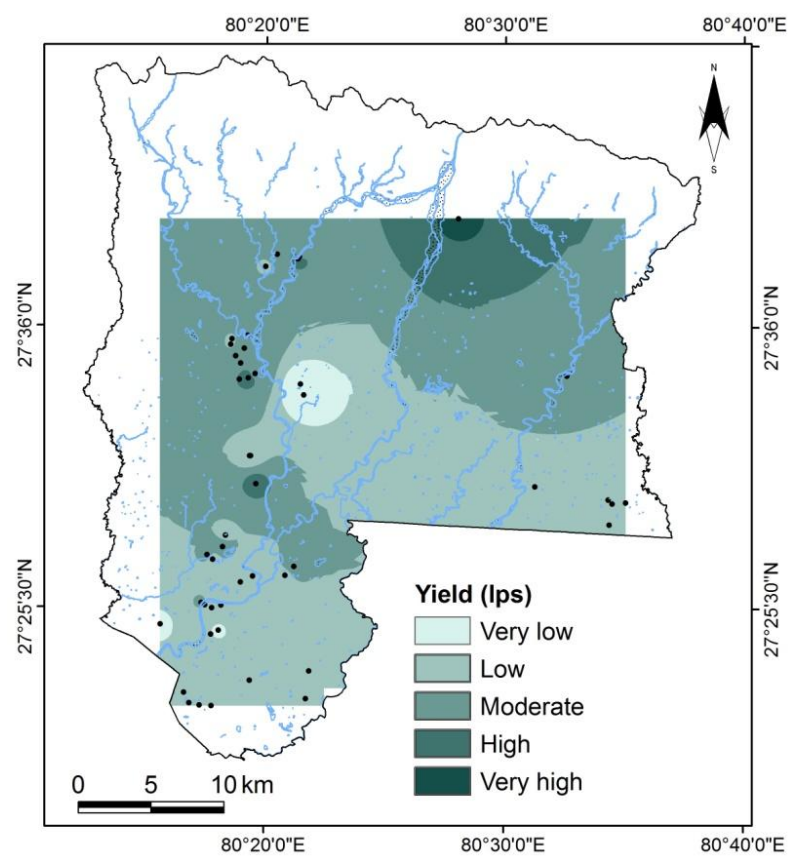

Fig. 5. Yield from shallow well $(<25 m)$. The black dot represents the locations of wells with yield used in the present study.

Likewise, in the western part, this zone is extended from Bishunpura VDC in the central part to 
Maryadpur VDC in the south central part of the district. The other mapped area, especially the southern part, falls in the low yield zone (well yield around 10-15 lps). However, the shallow well located at Manigram has exceptionally high yield (91.68 lps). This value can be justified by the transmissivity map that shows transmissivity value of $>7000 \mathrm{~m}^{2} /$ day) at Manigram (Sharma, 1995). Since the high value has been recorded in only one well, this well has been excluded while preparing the yield potential map of shallow aquifer.

\section{Ground water potential}

More reliable and accurate delineation of the groundwater potential map with the borehole and pumping test database is possible in the GIS environment. The groundwater potential map of Rupandehi district for shallow aquifer that is prepared by overlaying the distribution of percentage of aquifer material and yield values shows that the highest potential lies in the northern part of the district and some patches occur around Bishunpura and Dhamauli VDCs along the Danav River in the west and Chhotki Ramnagar in the east (Figure 6). The Gajedi and Suryapura VDCs south of the east-west highway in the western part and the road section on the Siddharthanagar Municipality can be categorized as the areas of very low groundwater potential.

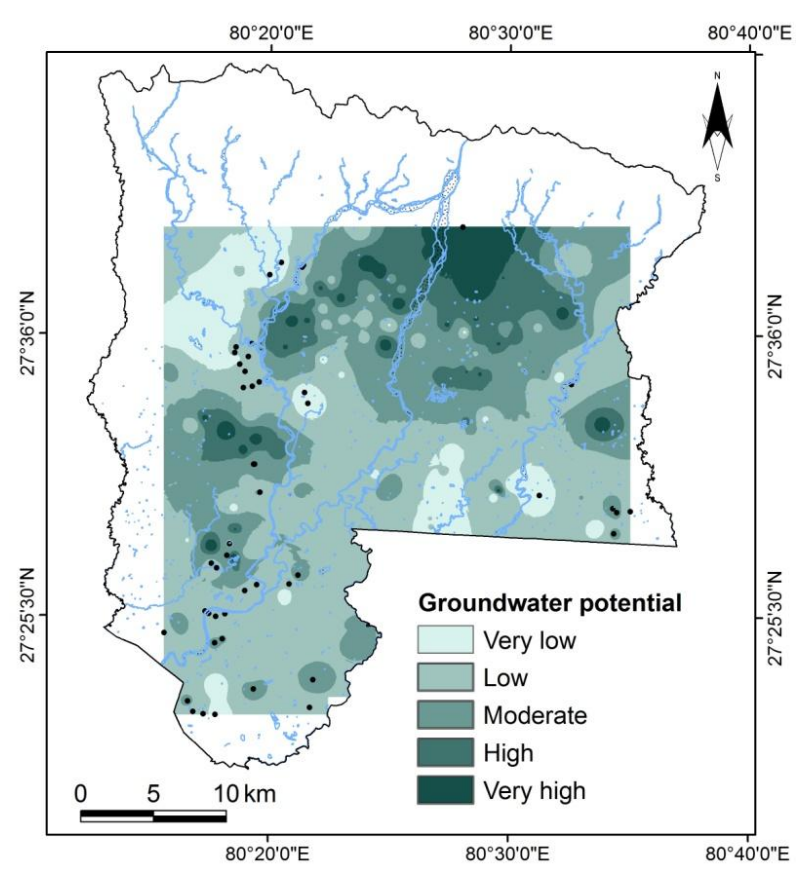

Fig. 6. Shallow groundwater potential in Rupandehi district.
The groundwater potential is indicative of the occurrence of groundwater in an area, which may be changed with time depending upon the sedimentation nature and groundwater drafting.

\section{CONCLUSION}

Preparation of hydrogeological database is a preliminary task towards delineating the groundwater potential map in an area. In the present study, more than 300 well data has been used to prepare hydrogeological database of Rupandehi district in GIS environment followed by further analysis of the hydrogeological parameter of the wells drilled in the Indo-Gangetic Plain. The groundwater potential map of the area shows that the northern part of the district as well as along the Danav river is having high shallow groundwater potential. The present approach can be applied in other areas and the output map would better reflect the field condition if additional parameters like hydraulic conductivity can also be incorporated in the preparation of the map.

\section{REFERENCES}

Ali, Q. S. W.; Lal, D. and Ahsan, Md J. (2015). Assessment of groundwater potential zones in Allahabad district by using remote sensing \& GIS techniques. International Journal of Applied Research, 1 (13): 586-591.

BLGWP (Bhairahawa Lumbini Groundwater Project) (1998a). Report of tubewells (Stage II), Rupandehi district, Technical Report: vol 2, Government of Nepal.

BLGWP (Bhairahawa Lumbini Groundwater Project) (1998b). Summary of tubewells (Stage I, II and III), Rupandehi district: Technical report vol.4, Groundwater Resources Development Board, Government of Nepal.

Groundwater Development Consultant (GDC) Ltd., Hunting Technical Services Ltd., and East Consult (P) Ltd. (1994a). Reassessment of the groundwater development strategy for irrigation in the Terai, vol. I (Main Report), and maps. Government of Nepal, Department of Irrigation, Groundwater Resources Development Project.

Groundwater Development Consultant (GDC) Ltd., Hunting Technical Services Ltd., and East Consult (P) Ltd. (1994b). Re-assessment of the Groundwater Development strategy for irrigation in the Terai, vol. 3 (Groundwater) 
and maps. Government of Nepal, Department of Irrigation, Groundwater Resources Development Project.

Naveenkumar; Soraganvi, V. S. and Hooli, S. S. (2015). Groundwater Potential Mapping in a Part of Malaprabha River Basin using Remote Sensing Data and Geographic Information System (GIS). Journal of Environment and Earth Science, 5 (5): 41-47.

Magesh, N. S.; Chandrasekar, N. and Soundranayagam, J. P. (2011). Delineation of groundwater potential zones in Theni district, Tamil Nadu, using remote sensing, GIS and MIF techniques. Geoscience Frontiers, 3 (2): 189-196.

Rao, G. K. and Pathak, D. (1996). Hydrogeological conditions in the Terai plain of Nawalparasi District, Lumbini Zone, Nepal with special reference to groundwater recharges. Journal of Applied Hydrology, 9: 69-75.

Suganthi, S.; Elango, L. and Subramanian, S. K. (2013). Groundwater potential zonation by Remote Sensing and GIS techniques and its relation to the Groundwater level in the Coastal part of the Arani and Koratalai River Basin, Southern India. Earth Sciences Research Journal, 17 (2): 87-95.
Sharma, C. K. (1995). Shallow (Phreatic) aquifers of Nepal. Pub. Sangeeta Sharma, Bishal Nagar, 272+p.

Srinivasa, Y. and Jugran, K. (2003). Delineation of ground water potential zone and zones of groundwater suitable for domestic purposes using Remote Sensing \& GIS. Hydrological Sciences Journal des Sciences Hydrologyques, 48 (5): 821-833.

Tibbitts, G. C.; Ogilbee, W. and Sharma, C. K. (1973). Groundwater resources investigations in Lumbini Zone, western Terai, Nepal. Interim administrative report, Engineering Division, United States Agency for International Development (USAID) Nepal.

Tillson, D. (1985). Hydrogeological technical assistance to the Agricultural Development Bank of Nepal, ADB/UNDP report.

Upreti, S. R. (1989). Shallow wells drilling, testing and monitoring in 1988/89, basic documentation and preliminary interpretation, Shallow groundwater investigations in Terai: Rupandehi district, Technical Report No. 14, UNDP and HMG/N. 